\title{
Development of a bacteria-based self healing concrete
}

\author{
Henk M. Jonkers \& Erik Schlangen \\ Delft University of Technology, Faculty of Civil Engineering and GeoSciences/Microlab, \\ Delft, The Netherlands
}

\begin{abstract}
Concrete structures usually show some self-healing capacity, i.e. the ability to heal or seal freshly formed micro-cracks. This property is mainly due to the presence of non-hydrated excess cement particles in the materials matrix, which undergo delayed or secondary hydration upon reaction with ingress water. In this research project we develop a new type of self-healing concrete in which bacteria mediate the production of minerals which rapidly seal freshly formed cracks, a process that concomitantly decreases concrete permeability, and thus better protects embedded steel reinforcement from corrosion. Initial results show that the addition of specific organic mineral precursor compounds plus spore-forming alkaliphilic bacteria as self-healing agents produces up to $100-\mu \mathrm{m}$ sized calcite particles which can potentially seal micro- to even larger-sized cracks. Further development of this bio-concrete with significantly increased self-healing capacities could represent a new type of durable and sustainable concrete with a wide range of potential applications.
\end{abstract}

\section{INTRODUCTION}

The occurrence of autogenous healing -or self-healingof cracks in concrete has been recognized in several recent studies (Neville 2002; Reinhardt \& Jooss 2003). The capacity for crack-healing in most common types of concrete, however, appears to be limited to micro-cracks, i.e. cracks with widths up to $0.1-0.2 \mathrm{~mm}$ (Li \& Yang 2007; Edvardsen 1999). The mechanism of the self-healing process may actually differ, as it mainly depends on the composition of the concrete mixture. For example, crack-healing in mortar of centuries-old brick buildings in Amsterdam canals has been observed, and here the process was contributed to dissolution and re-precipitation of calcium carbonate within the mainly lime-based mortar matrix. Crack-penetrating water would not only dissolve calcite $\left(\mathrm{CaCO}_{3}\right)$ particles present in the mortar matrix, but would also react together with atmospheric carbon dioxide with not fully hydrated lime constituents such as calcium oxide and calcium hydroxide according to the following reactions:

$$
\begin{aligned}
& \mathrm{CaO}+\mathrm{H}_{2} \mathrm{O} \rightarrow \mathrm{Ca}(\mathrm{OH})_{2} \\
& \mathrm{Ca}(\mathrm{OH})_{2}+\mathrm{CO}_{2} \rightarrow \mathrm{CaCO}_{3}+\mathrm{H}_{2} \mathrm{O}
\end{aligned}
$$

The freshly produced minerals from the above stated reactions (1) and (2) and from dissolved and recrystallized calcite minerals, precipitated on the surface of cracks what resulted in crack-sealing and concomitant reduction in permeability of the mortar. The healing potential of this system was directly related to the amount of non-reacted lime particles within the set mortar. Modern concrete structures, usually based on Portland cement with varying percentages of cement replacements such as fly ash, silica fume or blast-furnace-slag, also feature a certain potential for autonomous crack-healing. The process in this modern concrete is, however, analogous to that of lime-based mortars, as excess non-hydrated or only partially hydrated cement particles undergo delayed or secondary hydration with ingress water. Particularly concrete produced with mixtures characterized by a low water to cement weight ratio such as high strength concrete or polymer fiber reinforced concrete (Li \& Yang 2007) may feature high crack-healing potential due to the relatively high amount of nonreacted cement particles present in the concrete matrix. A high crack-healing potential of concrete structures is beneficial as it makes the material stronger and above all more durable. A continuous healing of particularly surface cracks results in a decreased permeability of the material and a significantly reduced risk of premature matrix degradation and corrosion of the embedded steel reinforcement due to ingress water and aggressive chemicals. One reason why traditional concrete is not routinely based on a low water to cement weight ratio and concomitant high self-healing potential is the high costs involved. Moreover, current policy is to reduce the amount of cement needed in a concrete mixture, as its production is environmentally 
unfriendly due to high energy consumption and concomitant atmospheric $\mathrm{CO}_{2}$ emissions (Gerilla et al. 2007; Peris Mora 2007). However, concrete with low cement content, i.e. based on a high water/cement ratio, will likely not feature a significant autogenous crack-healing capacity as most, if not all, cement particles have already undergone full hydration during early age. Thus, to improve the durability of such a relatively cheap and environmentally sustainable concrete, an alternative self-healing mechanism has likely to be incorporated. One such a mechanism can possibly be provided by mineral-producing bacteria. Natural soils are the habitat of a large variety of non-pathogenic bacteria and several of those have been reported to be potent bio-mineral producers (Stocks-Fischer et al. 1999; Castanier et al. 1999; Douglas \& Beveridge 1998). Also alkalic lakes (Nielsen et al. 1994) and even certain natural stones and minerals harbor groups of specialized bacteria (Clegg 2001), termed alkaliphilic- and endolithic bacteria respectively, which include calcite-producing bacteria (Rodriguez-Navarro et al 2003; Fajardo \& Nicholson 2006; Stocks-Fischer et al. 1999). Particularly bacteria of the latter two groups appear promising for application as self-healing agent in concrete, as the environments they originate from show a certain analogy with the concrete matrix, i.e. stony, and a highly alkaline $\mathrm{pH}$. The main goal of the present study therefore was to investigate whether concrete-immobilized calcite-producing bacteria could potentially represent an alternative crack-healing mechanism in concrete.

\section{MATERIALS AND METHODS}

\subsection{Selection and cultivation of calcite-producing bacteria}

The following species of spore-forming alkaliphilic bacteria were obtained from the German Collection of Microorganisms and Cell Cultures (DSMZ), Braunschweig, Germany: Bacillus cohnii DSM 6307; Bacillus halodurans DSM 497 and Bacillus pseudofirmus DSM 8715. Potential for spore-formation and calcite production of these strains was tested by cultivation in specific media. Basic medium was composed of $0.2 \mathrm{~g} \mathrm{NH}_{4} \mathrm{Cl}, 0.02 \mathrm{~g} \mathrm{KH}_{2} \mathrm{PO}_{4}, 0.225 \mathrm{~g} \mathrm{CaCl}_{2}, 0.2 \mathrm{~g}$ $\mathrm{KCl}, 0.2 \mathrm{~g} \mathrm{MgCl} \cdot 6 \mathrm{H}_{2} \mathrm{O}$ per liter Milli-Q ultra pure water plus $1 \mathrm{ml}$ trace elements solution SL12B and $0.1 \mathrm{~g}$ yeast extract. For sporulation (spore-formation) experiments, $50 \mathrm{mM} \mathrm{NaHCO} 3,50 \mathrm{mM} \mathrm{Na} 2 \mathrm{CO}_{3}$ and $20 \mathrm{mM}$ sodium citrate was added to the basic medium. To investigate calcite production potential of these bacteria in liquid media, basic medium was amended with $50 \mathrm{mM} \mathrm{NaHCO}, 100 \mathrm{mM}$ sodium citrate and $25 \mathrm{mM}$ $\mathrm{CaCl}_{2}$. The high concentration of sodium citrate in the later medium was needed to inhibit abiotic calcite formation.

\subsection{Effect of bacteria and organics additions on paste strength}

As both bacteria and organic bio-mineral precursor compounds need to be incorporated in the material matrix to obtain an autogenous self-healing concrete, their potential negative effect on strength characteristics must first be quantified. Therefore, to determine the influence on compressive and splitting-tensile strength, cement paste samples with and without (control) additions were prepared and tested. Aggregate material was excluded from the paste mixture in order to fully expose the effect of additions to binder strength. Before addition to the fluid paste, a B.pseudofirmus culture was cleaned from medium residues by centrifugation, washing and resuspension of the cell pellet in tap water. The obtained clean spore suspension was subsequently diluted with the paste make up water to obtain a final cell density of $6 \times 10^{8} \mathrm{~cm}^{-3}$ cement stone. Sets of 6 replicate test specimens with dimensions of $4 \times 4 \times 4 \mathrm{~cm}$ were tested for compressive strength after 3,7 and 28 days curing. Splitting-tensile strength tests were performed on cement stone cylinders $(2.2 \mathrm{~cm}$ diameter, $3 \mathrm{~cm}$ height) containing different organics representing potential bio-mineral precursor compounds (see Figure 3). Concentration of added organics amounted to $0.5 \%$ of cement weight, and triplicate cylinders for each compound were tested after 28 days curing. Ordinary Portland cement (ENCI CEMI 32.5R) and a water to cement weight ratio of 0.4 and 0.5 , for bacteriaand organic compound amended samples respectively, was used for the preparation of the cement paste test specimens.

\subsection{Calcite-producing potential of paste-immobilized bacteria}

Cement paste cylinders ( $2.2 \mathrm{~cm}$ diameter, $3 \mathrm{~cm}$ height) with a water to cement weight ratio of 0.5 were prepared without any further additions (series A: control), with calcium lactate $(0.5 \%$ of cement weight: series $B)$ and with $0.5 \%$ calcium lactate plus $1 \times 10^{8}$ B.cohnii spores $\mathrm{cm}^{-3}$ paste (series C). After 7 days curing in sealed plastic vials cylinders were cut in $0.5-\mathrm{cm}$ thick slices, and subsequently incubated in tap water. The paste slices were rinsed with distilled water after 10 days incubation and calcite formation on the specimen surfaces were examined with a Philips XL30 environmental scanning electron microscope (ESEM) without any further sample preparation.

\section{RESULTS}

\subsection{Spore formation and calcite production in liquid cultures}

All three investigated bacterial species grew well in the specified sodium citrate-amended medium and 


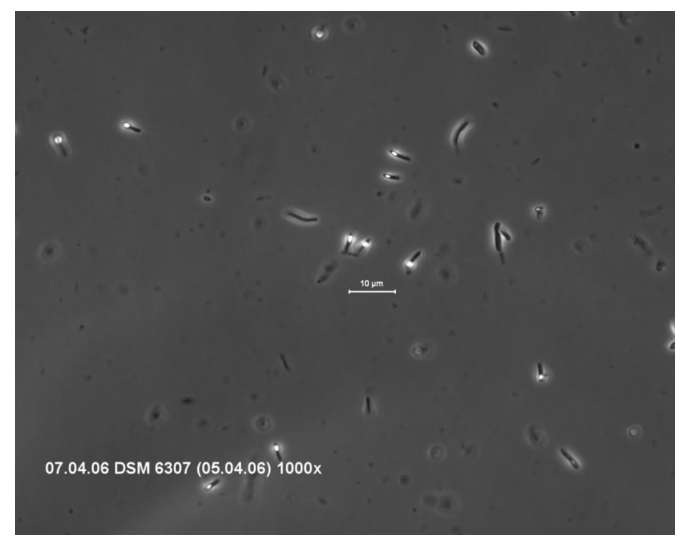

Figure 1. Endo-spore formation in B.cohnii culture.

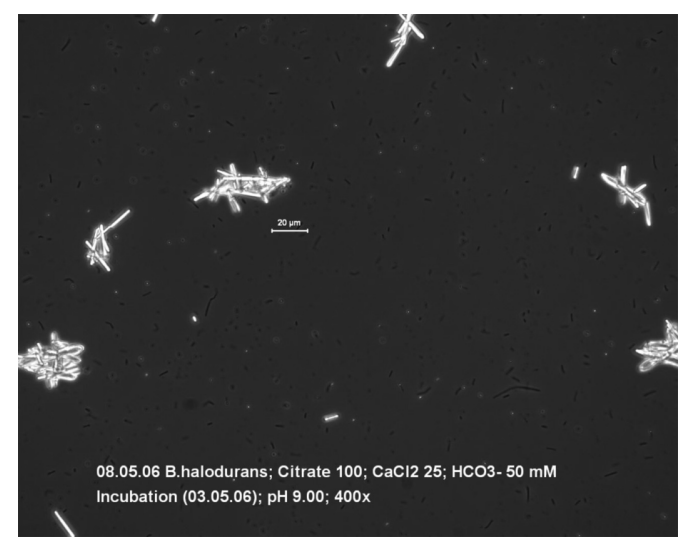

Figure 2. Calcite production in B.halodurans culture.

produced copious spores during the late exponential growth phase. Figure 1 shows a light microscopic picture of a B.cohnii culture in which the produced endospores appear as bright intracellular spheres. The bright appearance is due to strong light- scattering of the thick-walled endospores. Moreover, all bacteria proved potent calcite producers in media amended with calcium chloride and a high concentration of sodium citrate but relatively low inorganic carbon content (Figure 2). No calcite formation was observed in abiotic cultures (same medium but not inoculated with bacteria). Although both free calcium ions and inorganic carbon was present in this specific medium, no abiotic calcite formation occurred due to the calciumchelating efficiency of present citrate. Bacterial cultures did produce calcite, as metabolic conversion of citrate resulted in increased alkalinity and decreased chelating potential.
Control versus B.pseudofirmus

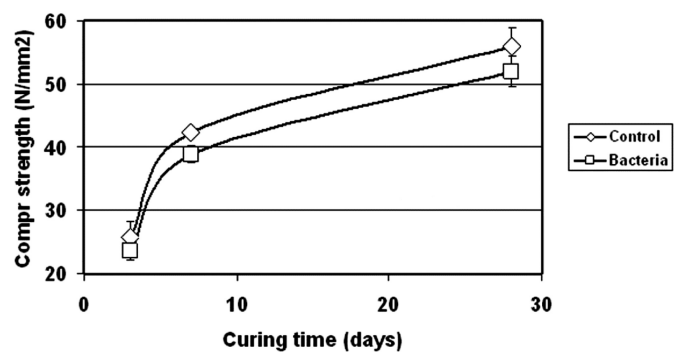

Figure 3. Compressive strength development of control and bacteria-added cement paste samples in time.

\section{Split test $t=28$ days}

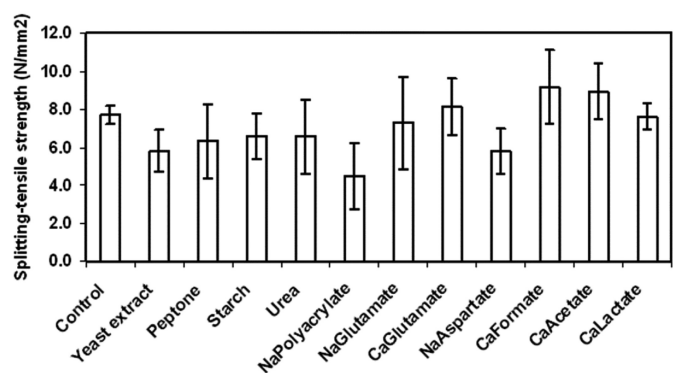

Figure 4. Splitting-tensile strength of organic compound-enriched $(0.5 \%$ of cement weight $)$ cement paste after 28 days curing.

\subsection{Strength of bacteria and organic compound-amended paste specimens}

As organic additives to paste mixtures can result in unwanted strength loss, the effect of bacteria and organic compounds (potential bio-mineral precursors) on compressive or splitting-tensile strength was investigated. Incorporation of a high number of bacterial spores in the paste $\left(6 \times 10^{8} \mathrm{~cm}^{-3}\right)$ resulted in about $10 \%$ decrease in compressive strength as values amounted (compared to controls) to 91,92 and $93 \%$ after 3, 7 and 28 days curing respectively (Figure 3 ). Additions of different organic compounds $(0.5 \%$ of cement weight) also affected splitting-tensile strength of the paste. However, the extent of change (compared to the control) varied as this depended on compound identity (Figure 4). Six out of 11 tested compounds (yeast extract, peptone, starch, urea, sodium-polyacrylate and sodium-aspartate) resulted in a substantial reduction in strength after 28 days curing. However, 5 compounds (sodium- and calcium-glutamate, calcium-formate, -acetate, and -lactate) appeared not 


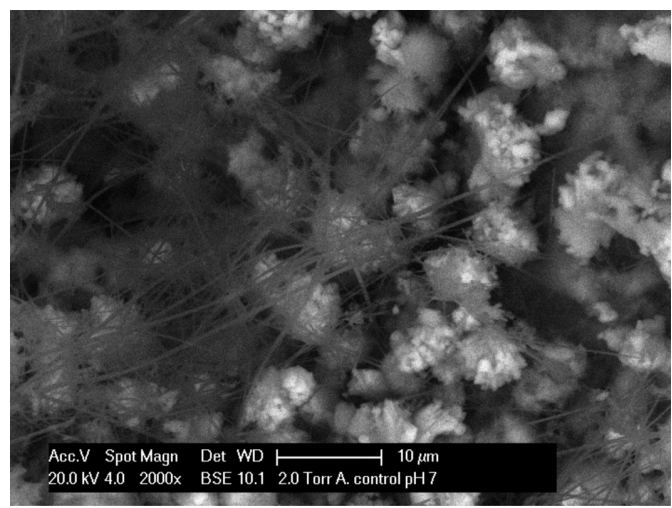

Figure 5A. Surface of control paste specimen.

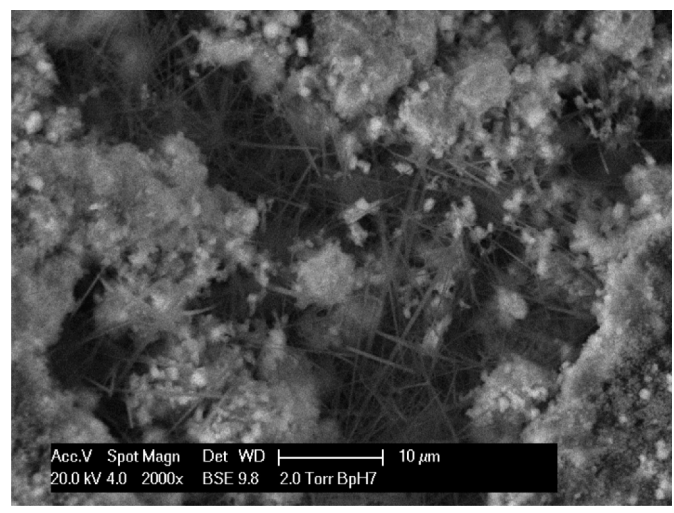

Figure 5B. Calcium lactate-enriched paste specimen.

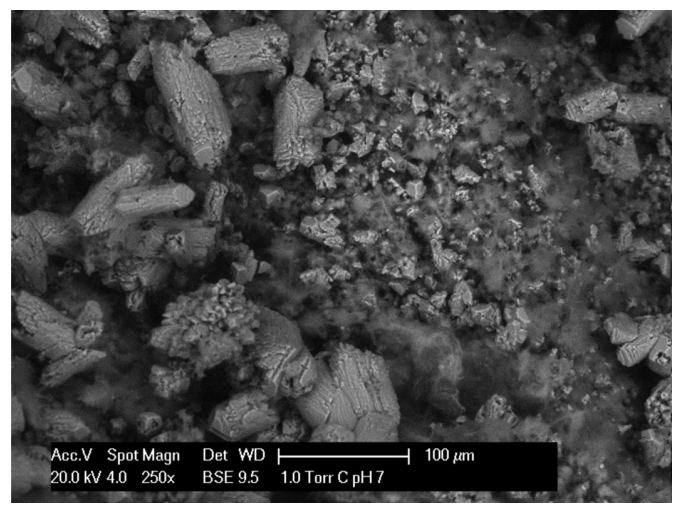

Figure 5C. Calcite particle formation on surface of B. cohnii plus calcium lactate-enriched specimen; note scale bar.

to result in strength loss. It should be noted, however, that standard deviations of obtained data were large, and therefore these results should be interpreted with care.

\subsection{Calcite-producing potential of paste-immobilized bacteria}

ESEM analysis of the surface of tap water incubated paste samples showed major differences between control (no additions), calcium lactate-amended, and calcium lactate plus bacteria-amended specimens (Figure 5A, B and $\mathrm{C}$ respectively). On the surface of control- and lactate-enriched specimens, clusters of small $(2-5 \mu \mathrm{m})$ calcite minerals as well as massive C-S-H (calcium silcate hydrate)-like filaments were formed. In contrast, paste specimens with incorporated calcium lactate plus bacteria produced, in addition to small minerals and C-S-H-like filaments, large-sized (up to $100 \mu \mathrm{m}$ ) robust calcite precipitates.

\section{DISCUSSION}

Although concrete with a high self-healing (crackhealing) potential is wanted, the addition of healing agents such as bacteria and/or (organic) chemical compounds to the paste may result in unwanted decrease of strength properties. A $10 \%$ compressive strength loss due to incorporation of bacteria (B.pseudofirmus) was observed in this study. However, such a loss in strength may be acceptable when this is compensated for by a substantial increase in the materials self(crack)-healing capacity. The two-component selfhealing system tested here (incorporated bacteria plus calcium lactate) resulted in the formation of $100-\mu \mathrm{m}$ sized calcite particles on specimen surfaces in contrast to controls (no additions or calcium lactate only), where much smaller sized particles were formed. The results of this preliminary study thus indicate that the two-component system may be characterized by a superior crack-healing potential, as much larger cracks can theoretically be sealed by the larger calcite particles produced. It remains to be evaluated, however, to what extent increased bacterial mineral production on (crack) surfaces results in decreased permeability, and thus better protection of the underlying material matrix. A lowered permeability due to healing of cracks would result in a decreased ingress rate of aggressive chemicals, which could lead to premature matrix degradation or corrosion of embedded steel reinforcement. Self-healing with the aid of incorporated bacteria could thus result in a better healing (sealing of larger cracks) compared to autogenous healing of non-amended pastes. It has been observed in previous studies that particularly high strength concrete, characterized by a low water to cement weight ratio, has a substantial self-healing capacity (Edvardsen 1999; Neville 1999). This is due to the large amount of non- or only partially hydrated cement particles present in the material matrix. Such particles will undergo secondary hydration with crack ingress water, a process that was also observed in this study for the 
control samples (Figure 5A and B). The capacity of this autogenous chemical self-healing mechanism is directly related to the amount of non- (fully) hydrated cement particles present in the material matrix. The maximum crack width that can be self-healed in such high strength concrete appears to be limited to $0.1 \mathrm{~mm}$ (Edvardsen 1999; Li \& Yang 2007). From an economical and environmental point of view, however, such a cement particle-based chemical self-healing system is not preferred due to the high costs of cement and the high amount of $\mathrm{CO}_{2}$ that is released during its production (Gerilla et al. 2007; Peris Mora 2007). A two-component self-healing system based on bacterial mineral production as proposed in this study would for the latter two reasons be preferential, and moreover, the size of bacterially produced minerals suggests that larger cracks could potentially be healed. The mechanism of bacterially induced self-healing is based on the metabolic conversion of suitable organic compounds to calcite, e.g. represented by the bio-conversion of calcium-formate with portlandite present in the paste matrix:

$$
\mathrm{Ca}\left(\mathrm{CHO}_{2}\right)_{2}+\mathrm{Ca}(\mathrm{OH})_{2}+\mathrm{O}_{2} \rightarrow 2 \mathrm{CaCO}_{3}+2 \mathrm{H}_{2} \mathrm{O}
$$

In several previous studies, bacteria were also applied for durability improvement or concrete repair. In those studies, the calcite production potential of a special group of ureolytic bacteria and their applicability to concrete was investigated (Bang et al. 2001; Ramachandran et al. 2001; De Muynck et al 2007; Ramakrishnan 2007). However, in those studies bacteria and their required substrates (urea plus calcium chloride) were applied externally, i.e. on set concrete specimens. As the bacteria and substrates were not part of the original concrete mixture, this type of repair can not be considered as self-healing. In the present study, however, both bacteria and mineral precursor compounds were mixed with the paste and became therefore an integral part of the material. In a parallel study it was shown that the spores of specialized alkaliphilic bacteria, such as the ones used in this study, survive within the concrete matrix and can be activated by a combination of (ingress) water and a suitable growth substrate (Jonkers 2007; Jonkers \& Schlangen 2007). What is still unclear, however, is the extent of bio-availability of organic compounds mixed with the cement paste. It remains to be quantified which part of added organics is actually available for the bacteria (e.g. by being dissolved in the matrix capillary water), and which part will be chemically bound within cement hydration products and matrix thus being inaccessible for bacteria. However, the results of this study indicate that at least a part of the added organics was available for metabolic conversion, as produced calcite particles were much larger in bacteria plus organics-amended paste (Figure 5C) compared to controls.
In conclusion we can state that the investigated bacterially based two-component system seems a promising- and definitely more sustainable, alternative to high strength pastes which are characterized by a high cement content. However, the self-healing capacity (crack-sealing and concomitant permeability reduction) remains to be quantified in future studies.

\section{ACKNOWLEDGEMENTS}

We would like to thank Arjan Thijssen for help with ESEM analysis, and the Delft Center for Materials (DCMat: www.dcmat.tudelft.nl) for financial support for this study.

\section{REFERENCES}

Bang, S.S., Galinat, J.K., Ramakrishnan, V. 2001. Calcite precipitation induced by polyurethane-immobilized Bacillus pasteurii. Enzyme and Microbial Technology 28: 404-409.

Castanier, S., Le Metayer-Levrel, G. \& Perthuisot J.P. 1999. $\mathrm{Ca}$-carbonates precipitation and limestone genesis - the microbiogeologist point of view. Sedimentary Geology 126: 9-23

Clegg, J.S. 2001. Cryptobiosis - a peculiar state of biological organization. Comparative Biochemistry and Physiology Part B 128(8): 613-624.

De Muynck, W., De Belie N. \& Verstraete W. 2007. Improvement of concrete durability with the aid of bacteria. Proc of the 1 st Int conference on self healing materials 18-20 April 2007, Noordwijk aan Zee, The Netherlands; p: 1-11.

Douglas, S. \& Beveridge T.J. 1998. Mineral formation by bacteria in natural microbial communities. FEMS Microbiology Ecology 26(2): 79-88.

Edvardsen C. 1999. Water permeability and autogenous healing of cracks in concrete. ACI Materials Journal 96(4): 448-454.

Fajardo-Cavazos, P. \& Nicholson, W. 2006. Bacillus endospores isolated from granite: Close molecular relationships to globally distributed Bacillus spp. from endolithic and extreme environments. Appl. Environm. Microbiol. 72(4):2856-2863.

Gerilla G.P., Teknomo K. \& Hokao K. 2007. An environmental assessment of wood and steel reinforced concrete housing construction. Building and Environment 42: 2778-2784.

Jonkers H.M. 2007. Self healing concrete: a biological approach. In S. van der Zwaag (ed.) Self healing materials - An alternative approach to 20 centuries of materials science. Springer, The Netherlands; p: 195-204.

Jonkers H.M. \& Schlangen E. 2007. Self-healing of cracked concrete: A bacterial approach. In Carpenteri et al (eds): Proc of FRACOS6: Fracture mechanics of concrete and concrete structures, Catania, Italy, 17-22 June 2007; p: $1821-1826$.

Li V.C. \& Yang E. 2007. Self healing in concrete materials. In S. van der Zwaag (ed.) Self healing materials $-A n$ alternative approach to 20 centuries of materials science. Springer, The Netherlands; pp: 161-194. 
Neville A.M. 2002. Autogenous healing - A concrete miracle? Concrete Int 24(11):76-82.

Nielsen, P., Rainey, F.A., Outtrup, H. Priest F.G. \& Fritze D. 1994. Comparative 16s Rdna sequence-analysis of some alkaliphilic Bacilli and the establishment of a 6th ribosomal-RNA group within the genus Bacillus. FEMS Microbiol Lett 117(1): 61-65.

Peris Mora E. 2007. Life cycle, sustainability and the transcendent quality of building materials. Building and Environment 42:1329-1334.

Ramachandran, S.K., Ramakrishnan, V., Bang, S.S. 2001. Remediation of concrete using micro-organisms. ACI Materials Journal 98(1):3-9.

Ramakrishnan, V. 2007. Performance characteristics of bacterial concrete-A smart biomaterial. First Int conference on recent advances in concrete technology 19-21 September 2007, Washington DC, USA; pp:67-78.

Reinhardt H.W. \& Jooss M. 2003. Permeabilitiy and selfhealing of cracked concrete as a function of temperature and crack width. Cement and Concrete Res 33:981-985.

Rodriguez-Navarro, C., Rodriguez-Gallego, M., Ben Chekroun, K. \& Gonzalez-Munoz, M.T. 2003. Conservation of ornamental stone by Myxococcus xanthusinduced carbonate biomineralization. Appl. Environm. Microbiol. 69(4): 2182-2193.

Stocks-Fischer, S., Galinat J. K. \& Bang S.S. 1999. Microbiological precipitation of $\mathrm{CaCO} 3$. Soil Biology and Biochemistry 31:1563-1571. 